\title{
The Color of Class: The Color Purple through a Marxist Feminist
}

\section{Lens}

\author{
Shivani Bhatt \\ PhD English \\ Ambedkar University of Delhi \\ Delhi, India \\ shivanibhatt25@gmail.com
}

The paper revolves around the interplay of gender, race and sexuality under the canopy of Capitalism in Alice Walker's The Color Purple. By evoking Walker's subtle exploration of the nexus between patriarchy, race and capitalism, the paper aims to dwell on these complementary forces that operate elliptically, furthering and constructing the concentric circles of Marxism and Feminism. In addition, the analysis extends the Marxist (feminist) notion of simply instituting a relationship between women's uncompensated labor with GDP computation to a more nuanced study of hetero-patriarchal structures of hegemony. Furthermore, the paper looks at the visual dimensions, the color of the exquisite purple flowers that Shug describes to Celie, blossom all through in Spielberg's 1985 adaptation of the movie, justifying the title not only for the characters but for the onlookers alike. Though written at the time of a convalescing recession-hit economy, The Color Purple is situated in 1809 when Walker's ancestors were fighting against racial discrimination, slavery and abuse. As a just tribute to her grandmother who was murdered by 
a spurred lover, Walker presents how love and female solidarity are highly empowering and milestones in self-discovery. In the novel, Celie's perpetual exploitation at the hands of Mister (Albert) is representative of the oppression in the patriarchal structures - on a microcosmic level, while the White denigration and domination over the colored is emblematic of the larger subservience to the systems of power.

The domain of power almost always assumes a superior subordinate relationship; with the intersection of race, class and gender, the poor black woman's experience plummets to the lowest rung. Racial inferiority, economic dependency and patriarchal domination, triply marginalizes women which is best captured by Mister's outburst to Celie "You black, you pore, you ugly, you a woman. Goddam, he say, you nothing at all” (Walker 108). Celie's position and her various levels of subjugation give rise to the debate of Marxism and Feminism and their juncture at racism which shows the contestation of what subsumes the other and to what degree. Kimberley Crenshaw notes "intersectional experience [is] greater than the sum of racism and sexism" (140). In defining intersectionality, she talks about it as a metaphor for the black woman's experience not just on the axis of being a women or racially inferior but a collision of many forces that are not anticipated as arising simultaneously. Although Walker's novel is anachronistic for her theory but it is still relevant as historically it traces the women's experiences from first wave to the third wave feminism. Earlier equality meant white women's struggle, whereas with the coming of the third wave feminism it meant celebration of the differences of experience of the third world women, along with deviant sexualities. Not just in the political domain then but economically too, intersectionality expands the scope of feminist theory.

Heidi Hartmann in her essay "The Unhappy Marriage of Marxism and Feminism: Towards More Progressive Union" talks about how Marxism is sex-blind and race blind, while Feminism is blind to history and stages of materialism (Hartmann 1979). The 
intersection of Marxism and Feminism must be in a way that it endeavors to understand the position of women in the capitalist society. While the traditional Marxists perceived Capitalism as drawing women directly into the labor force, the contemporary Marxists analyze all forms of the women's work as reproducing the capitalist arrangement. For ending the oppression of women under Capitalism and private property, not just their unaccounted domestic works need a reckoning but also equal pay, equal status and benefits of maternity, child care require emphasis too.

Gloria Joseph extends and critiques Hartmann's position in her essay “The Incompatible Menage a Trois: Marxism, Feminism and Racism" by talking about the incestuous child from the unhappy marriage of Feminism and Marxism being Racism (Joseph 1981). She explains through the essay how both white and black feminists should work in accordance against the injustices of white and male supremacy, while the protracted struggle against class and capital needs to be on an international level. She ends the essay by putting forth that "the Happy Divorce of Patriarchy, Capitalism and Racism.... [would lead to] the impending marriage of Black revolutionary socialism and socialist feminism" (104). By extension to the Marxist feminist critique of exploitative nature of relationships, there is an urge for socialist feminist approach to the equality that women need to be entrusted within both the private and public sphere.

In the novel, the apparatuses of power reinforce the oppression of women not only in their homes but also in the public sphere. While education does little good to the female characters, it does help Nettie enormously through her life. Nonetheless, the greatest hegemonic tool for subservience in the entire epistolary novel is the supplication to god. Alphonso tells Celie "You better not never tell anyone but God..." (7), the patriarchal warnings are mirroring the Church's sermonizing. The opium to the women's painful sufferings is the intoxication by religion. The patriarch like religion controls by instructing 
subjects of submission and obedience to the female pilgrims, the former by coercion and the latter by consent. In Walker's subtle critique of religion, God is presented both gendered and racist with "white hair and white eyes and white figure" and projected as a male figure in the letters Celie writes. For Celie, all the abuses hurled at her would get consolation at one destined day by God; the similar arrangements were used by the white men's colonizing and civilizing mission - the proselytizing of the black slaves helped in maintaining their authority.

The savior of Celie emanated in the form of Shug Avery. Avery epitomizes the concept of "womanism", the term coined by Walker as a celebration of the women of color, of strength, audacity, courage and the ability to love other women. She is presented as a highly romanticized figure from the onset; her arrival and subsequently her language make other characters a foil to her persona. Despite the socio-cultural relegation that other women of the times were set in, Shug Avery blossoms as a rebellious, economically independent woman. Making the tyrannical Mister perform at her beck and call, she is not just makes other men but Celie too fantasize about her. As Dixie Debates remarks, "Shug is, to all intents and purposes, a liberated woman and it is her art which enables her to be so" (112).

Pierre Bourdieu in "Forms of capital" talks about the conversion of one form of capital into another in the long run tied up to the economic capital (Bourdieu 1985). In the case of Shrug as a blues singer and Celie's skills as a seamstress, both possess diverse cultural capitals. Despite their skills being highly sporadic, they converge at a point where they are mutually healing and honing each other. For Shug Avery, her cultural capital (her singing talent) enables her to gain access to the Economic Capital; both of these capitals nurture the social capital and relationships with high ranked men, and all of these culminating into an unequalled reputation being her symbolic capital. For Celie who is devoid of any institutional learning, her sparse access to cultural capital comes through Nettie, while domestic skills comes more as a force than volition, her social capital stems from her 
association with the empowered Shrug Avery, and her inheritance of the estate later make her business venture successful. This economic capital's entry by way of her entrepreneurial endeavor also adds onto her psychological and social independence. While a certain section of critics believe that it is through her access into the domain of Capitalism that she gets the coveted independence socially and culturally, it is partly true as part of it also emanates from her travails in the whole journey, the networks and gains that she beheld. Pivotal in her growth as a person then an entrepreneur was her relationship with Shrug Avery. A life of drudgery she led - from no satisfaction with the forced abusive marriage and enslaved in Albert's farm, she got no remuneration for her toil, none for bringing his children or for taking care of his household. The respite, the love and much deserved respect all of these she developed in her bond with Shrug.

Strikingly, not only have women's domestic toils long not been instituted in the computation of national income and accounting, but regrettably the Capitalist enterprise thrives on this very premise of the extracting the surplus from the labor for the fulfillment of personal gains. Correspondingly, patriarchy operates in this framework of exploiting the false consciousness of the oppressed. The non-compensation of Celie's labor is clearly because of her gender but the nonpayment of Albert and Harpo at the hands of Albert's father is from a decidedly capitalistic point of view. Walker deftly creates the mirroring of oppression of Celie at the hands of Albert and of Albert's father's brazen attitude towards him and women in general.

Preceding Audre Lorde's Zami, in The Color Purple too there is a great illustration of female solidarity, the quilting as the leitmotif culminates with the success of Celie's pants business, transcending her from domesticity to the public domain. The sisterhood in the novel is reminiscent of the solidarity of the Amazonian women tribes who were had a similar framework of primitive trade and commerce, and a subsistence-based economy. This ultimate 
Amazonian fighter spirit is personified in the character of Sophia, wife of Harpo, who is absolutely indomitable in the authoritarian household of Mister. In the intrepid episode with the Mayor and his wife, she suffers not because she is hierarchically placed beneath the Mayor, but because her color and gender (coupled with her social status) make her subordinated at many levels. From an independent woman she becomes a slave because she refuses to enter the servility with a "hell no" and retaliates with punch to the mayor's humiliating slap. This is one decisive moment in the novel- when racial, sexual and class inferiority comes full circle. She gets imprisonment and after many mortifying penal proceeding is forced to accept the abusive service of Miss Millie, the mayor's wife. Sophia tells Eleanor Jane after her release, how irrespective of the colored's veneration of the whites, the blacks can never come to love the cruel whites; her predicament is the determining factor of the deep-rooted racism in the novel and around. And her trial is characteristic of the social coercion of the African Americans, emblematic also of the considerable disadvantages Walker's ancestor faced.

Celie realizes how oppression of race, class, gender is universally applicable through the large chunk of Nettie's letters that she later discovered. The letters from Nettie form an overarching frame narrative which is apprising Celie of the universality of oppression in her little sphere of domestic oppression. Nettie's association with Reverend Samuel's mission proves to be a lifelong learning exercise for her, of which she writes and continually describes to her sister. The visual contrasts of Nettie and Celie's locale are brought about stunningly through Steven Spielberg's 1985 film of the same name. The magnitude of description in the movie goes beyond the letters of the novel, the experiences of Georgia at Celie's place and the vast expanse of the world that Nettie goes through, the beautiful musical renditions and performances make the characters alive on screen. Spielberg's cinematic 
techniques of sideways camera placements and mostly the track in shots captured in the movie enhance the experience of crucial moments like - Celie's resistance after her irate confrontation with Mister.

However, the movie in comparison to the novel also has many inconsistencies, from adding the union of Shug with her reverend father and the highly musical ending to downplaying Shrug Avery and Celie's relationship which is shown only in an intimate scene between them. The music and tempo of the drumbeats of the Olinka tribes make the characters of Olivia and Adam less pronounced. However, the time constraint of a medium such as a movie makes lesser scope for details, also makes delineation of the plot smoother without digressions.

Unlike the novel, there is a major redemption of Mister in the denouement by reconciling Celie with her children and Nettie. His remorse absolved him of his past mistakes and his penance and efforts for Celie have a cathartic effect on the audience. The movie has many loopholes such as giving up of important motifs of quilting; Celie's spiritual awakening etc. making it less rounded than the novel. Nevertheless, the greatest advantage of the medium of a movie is its wider appeal and reach. If novel was considered a highly bourgeois form of writing then movies have the closest tie with Marxism with their ability to infiltrate through the politics of time, place and action in all material circumstances.

In summation, the movie skillfully captures Celie's progression as an independent entrepreneur. From silences to eloquence, Celie's womanist progression from powerlessness to power is paralleled with the writer's stages of progression: fighting the odds of patriarchy, making a room of their own literary vocation and creating a distinct ethos. However, the female characters in the novel not just require a room of their own, but a room for their children, a room for the unit of family dwelling. From the power mounted by money and by economic empowerment they are able to topple the edifice of patriarchal hegemony. Celie's 
business goes on to prove how Capitalist structures no more operate differently if both men and women become part of it. 


\section{Works Cited}

Althusser, Louis. "Ideology and Ideological State Apparatus (Notes Towards an Investigation)". Literary Theory: An Introductory Reader, ed. by Saugata Bhaduri and Simi Malhotra, Anthem Press India, 2010, 21-65. Print.

Bourdieu, Pierre, "The forms of Capital", Handbook Theory and Research for the Sociology of Education. ed. by J. Richardson, Westport, and CT: Greenwood, 1986, 241-258. Web. http://home.iitk.ac.in/ amman/soc748/bourdieu_forms_of_capital.pdf

Chesler, Phyllis. "Matriarchy in Amazon women". Women and Madness. Garden City, NY: Doubleday, 1972. 335-336. Print.

Crenshaw, Kimberley. "Demarginalizing the Intersection of Race and Sex: A Black Feminist Critique of Antidiscrimination Doctrine, Feminist Theory and Antiracist Politics".Feminist Theory and Antiracist Politics, University of Chicago Legal Forum: Vol. 1989:Iss. 1, Article 8. Web.

http://chicagounbound.uchicago.edu/uclf/vol1989/iss1/8

Hamilton, C. "Alice Walker's Politics or the Politics of the Color Purple". Journal of Black Studies, 18.3, 1988, 379-91. Web. 23 Oct. 2016. http://jbs.sagepub.com/content/18/3/379.short

Hartmann, Heidi. "The Unhappy Marriage of Marxism and Feminism: Towards a more Progressive Union". Marx Today . 1979, 201-28. Web. 22 Oct 2016. http://web.ics.purdue.edu/ hoganr/SOC\%20602/Hartmann_1979.pdf

Joseph, Gloria. “The Incompatible Menage a Trois: Marxism, Feminism and Racism”. Women and Revolution: A Discussion of the Unhappy Marriage of Marxism and Feminism. Ed. $\quad$ Lydia Sergent. 1981, 91-107. Web. 11 Nov 2016.

Lauret, Maria. "The Color Purple (1982)". Alice Walker. Houndsmills, Basingstoke, Hampshire: Palgrave Macmillan, 2011. Print. 
Lorde, Audre. Zami, a New Spelling of My Name. Trumansburg, NY: Crossing, 1982. Print. The Color Purple. Dir. Steven Spielberg. Prod. Kathleen Kennedy, Frank Marshall, By Menno Meyjes. Perf. Danny Glover, Adolph Caesar, Margaret Avery, Oprah Winfrey, Pugh, Whoopi Goldberg, and Akosua Busia. Warner Bros., 1985.DVD Walker, Alice. The Color Purple. New York: Harcourt Brace Jovanovich, 1982. Print. 